Manuela Ingaldi ${ }^{1}$, Martin Kotus $^{2}$

\title{
THE USE OF IMPORTANCE/PERFORMANCE ANALYSIS IN EVALUTION OF TRANPOSPORT SEVICE
}

\begin{abstract}
Services quality, because of their specificity, it is difficult to evaluate, especially since there is no their materiality, it can't be seen. Usually the gap between the expectations of customer and his perceptions in relation to a particular service is observed. In the chapter evaluation of transport service quality in chosen transport company in south of Poland was made. For this purpose the Importance/Performance analysis was used. First of all a survey was created. The same survey and its results were already used to evaluate quality management according to Servqual method in another paper (INGALDI M., WYWIAL S. 2015). In this case pairs of evaluations (Performance; Importance) were placed on Importance/Performance map. In this way the evaluation of the transport service was possible.
\end{abstract}

Key words: service quality, transport service, Importance/Performance analysis (IPA)

\section{Introduction}

A quality of a product or service refers to the perception (experience) of the degree to which the product or service meets the customer's expectation.

The quality analysis in case of the services is not as obvious as in case of the products. Examining the quality of the product we have tangible evidence of the level of quality. We can examine their dimensions, weight, the chemical, physical and mechanical properties, colour, smell, taste (INGALDI M., JURSOVA S. 2013; INGALDI M.,2013).

1 Dr inż., Politechnika Częstochowska, Wydział Zarządzania, Instytut Inżynierii Produkcji, e-mail: manuela@gazeta.pl

${ }^{2}$ Doc. Ing. PhD., Slovak University of Agriculture in Nitra, Faculty of Engineering, Department of Quality and Engineering Technologies, , e-mail: martin.kotus@uniag.sk 
Service quality very often is defined as comparison of customer expectation towards the service with its performance, e.g. reality. So service quality evaluation is the evaluation of how well a delivered service conforms to the customer's expectations.

Lots of scientists, working on service quality, decide to use some typical methods, such as Servqual, mystery shopping or critical incident technique (CIT). While Importance/Performance analysis (IPA), which is enough easy to conduct and is not time-consuming, is often skipped.

The Importance/Performance analysis, or importance/implementation analysis is a simple method used to measure the quality of services. This method is designed to determine the validity of the characteristics of the service and their evaluation by customers. Martilla and James, who were authors of this method, designed a measurement of the expectation and the significance of factors, variables affecting the quality of services, from the point of view of the purchasers (MARTILLA J.A., JAMES J.C. 1977).

IPA has been widely used in service industries such as travel and tourism, education, hospitals, and other sectors (WONG M.S., HIDEKI N., GEORGE P. 2011).

Nowadays, most people are focused on their continuous movement. They like to spend their free time far away from home, they want to run their business not only in the place of work, employers want to send their employees to the conferences, fairs, exhibitions, social events. For this purpose they use their own cars or decide to use public or private transport. So they benefit from a wide range of services offered by different transport companies. On the market there are many companies which offer such services. It is important that the customer based on his experiences or experiences of his friends, available information is able to choose the offer of high quality.

The purpose of this chapter is to evaluate the quality of transport services offered by one of companies from southern Poland. For this purpose the authors decided to use the Importance/Performance analysis. The analysis allowed to determine what is the level of services offered by 
the research company, according to customers and to provide suggestions for future directions of the company's activities.

\section{Methodology}

Customers responding to two types of scaled questions, make a double evaluation of the same dimensions of the service quality (which are the evaluation criteria from the point of view of the customers) - once because of their importance in the process of service delivery and second time, in terms of the level of implementation of these dimensions; which means that the first group of questions concerns the importance of each feature of offers in customers' selection decisions (expectation according to Servqual method), while the second group refers to the same features, but in relation to one specific offer of a service provider (perception according to Servqual method) (STOMA M. 2012). So partly the Importance/Performance analysis coincides with the Servqual method.

The results obtained with this analysis are summarized in the form of Importance/Performance map. In this way two evaluations of parameters mentioned earlier can be determined. The closer to the diagonal of the map the point is located, the more its performance is correlated with the needs of customers.

The two dimensional IPA model is divided into four quadrants with performance on the $\mathrm{x}$-axis and importance on the $\mathrm{y}$-axis. Model of IPA form of Importance/Performance map was presented in Figure 1.

Quadrant I is labelled as "Concentrate Here". Attributes that fall into this quadrant represent key areas that need to be improved with top priority. Quadrant I is called "the area of urgent needs". It is very important that the provider will focus special attention on them.

Quadrant II is labelled as "Keep up the good work". All attributes that fall into this quadrant are the strength and pillar of the organisations, and they should be the pride of the organisations. Quadrant II does not require from the service provider any serious action, only those necessary 
to maintain the current level of services. It is called "the area of reasonable property of needs".

\begin{tabular}{|c|c|}
\hline $\begin{array}{c}\text { Quadrant I } \\
\text { (High Importance/Low } \\
\text { Performance) }\end{array}$ & $\begin{array}{c}\text { Quadrant II } \\
\text { (High Importance/High } \\
\text { Performance) }\end{array}$ \\
\hline $\begin{array}{c}\text { Quadrant III } \\
\text { (Low Importance/Low } \\
\text { Performance) }\end{array}$ & $\begin{array}{c}\text { Quadrant IV } \\
\text { (Low Importance/High } \\
\text { Performance) }\end{array}$ \\
\hline
\end{tabular}

Fig. 1. Importance/Performance map.

Source: STOMA M. 2012

Quadrant III is labelled as "Low Priority". Thus, any of the attributes that fall into this quadrant are not important and pose no threat to the organisations. Quadrant II is called "the area of the improvement of service properties".

Quadrant IV is labelled as "Possible Overkill". It denotes attributes that are overly emphasized by the organisations; therefore, organisations should reflect on these attributes, instead of continuing to focus in this quadrant, they should allocate more resources to deal with attributes that reside in quadrant I. Quadrant IV is often called "the area of quality excess" (WONG M.S., HiDEKI N., GEORGE P. 2011).

The Importance/Performance analysis was modified many times, what can be exemplified with SWOT analysis (URBANIAK A. M. 2013). Model technique is a way to study the factors that affect the quality of the offer perceived by customers in the face of competing offers (RADKOWSKI K. 2005).

In the research presented in this chapter 134 customers of chosen transport company took part. The research had a form of the Internet survey about which fulfilment were asked customers after using the 
services offered by the research company. Electronic form provides greater anonymity, and at the same time facilitates data collection and sorting of results.

The proper preparation of the survey is very important element of the research. It should be remembered that the survey must be written in simple language that everyone can easily understand, and questions should not be too long, not to be boring for the respondent. Appropriate questions must also provide as much information about the quality of the test service as possible (LESTYÁNSZKA ŠKŮRKOVÁ K., INGALDI M. 2014; DZIUBA S.T., SZOŁTYSEK K., KOZYRA C. 2011).

The research was performed with the research of Servqual method presented in paper (INGALDI M., WYWIAL S. 2015). At the beginning customers had to evaluate their expectations for the transport service taking into account 22 statements (Table 1). These evaluations are Importance. Then they evaluated the actual service on the basis of these same statements, but in relation to the research transport company, e.g. Performance. Measurement of the service quality is made with a seven semantic rating scale (Likert scale), where the lowest level of the scale is: weak, and the highest: excellent (Table 2).

The average values of evaluations of all individual questions from both part of the Survey were calculated. Then the averages values for pair of statements (Performance; Importnance) were placed on the Importance/Perforance map. 
Table 1. Statements in surveys on customer's expectations [own study]

\begin{tabular}{|c|l|}
\hline No & Statement \\
\hline 1. & $\begin{array}{l}\text { The model transport company is equipped with modern transport } \\
\text { fleet. }\end{array}$ \\
\hline 2. & The model transport company has a modern computer system. \\
\hline 3. & Staff of the model transport company looks neat. \\
\hline 4. & $\begin{array}{l}\text { Promotional materials and Internet website of the model transport } \\
\text { company are legible. }\end{array}$ \\
\hline 5. & The model transport company is placed in a convenient location. \\
\hline 6. & The model transport company keeps the conditions of the contract. \\
\hline 7. & $\begin{array}{l}\text { The model transport company has a flawless documentation relating } \\
\text { to individual contracts. }\end{array}$ \\
\hline 8. & $\begin{array}{l}\text { The model transport company undertakes to perform services } \\
\text { within the specified time, it does not disappoint. }\end{array}$ \\
\hline 9. & $\begin{array}{l}\text { The model transport company is sensitive to the needs of individual } \\
\text { clients. }\end{array}$ \\
\hline 10. & $\begin{array}{l}\text { Staff of the model transport company always demonstrates a } \\
\text { willingness to help. }\end{array}$ \\
\hline 11. & $\begin{array}{l}\text { Staff of the model transport company inform the customer about the } \\
\text { conditions of the service. }\end{array}$ \\
\hline 12. & $\begin{array}{l}\text { Staff of the model transport company is ready for fast response on } \\
\text { the customer's need. }\end{array}$ \\
\hline 13. & Staff of the model transport company works smoothly and quickly. \\
\hline 14. & Staff of the model transport company is well qualified. \\
\hline 15. & $\begin{array}{l}\text { Staff of the model transport company has the knowledge to respond } \\
\text { the customers questions. }\end{array}$ \\
\hline 16. & $\begin{array}{l}\text { The model transport company cares about the current updates of its } \\
\text { offer. }\end{array}$ \\
\hline 17. & Staff of the model transport company behaves plausibly. \\
\hline 18. & $\begin{array}{l}\text { Staff of the model transport company is always nice and polite to } \\
\text { customers. }\end{array}$ \\
\hline 19. & The model transport company treats each customer individually. \\
\hline 20. & The model transport company provides services at a time \\
\hline
\end{tabular}




\begin{tabular}{|l|l|}
\hline & convenient to the customer. \\
\hline 21. & $\begin{array}{l}\text { The model transport company employs workers who devote their } \\
\text { full attention to the customer. }\end{array}$ \\
\hline 22. & $\begin{array}{l}\text { Staff of the model transport company understands specific } \\
\text { expectation of the customers. }\end{array}$ \\
\hline
\end{tabular}

Source: own study

Table 2. Scale of evaluation in the survey

\begin{tabular}{|c|c|c|c|c|c|c|}
\hline $\begin{array}{l}\text { Totally disagree } \\
\text { with the statement }\end{array}$ & $\begin{array}{r}\text { Totally agree } \\
\text { with the statement }\end{array}$ \\
\hline 1 & 2 & 3 & 4 & 5 & 6 & 7 \\
\hline
\end{tabular}

Source: Own study

\section{X.3. Characteristics of the research object}

The survey was conducted among customer of one of the transport companies from Czestochowa.

The company offers the transport services of passengers by buses, minibuses in Poland and European countries. Among the offers a customer can find daily transport of children and young people to the pool or to the cinema, school trips, transport of employees, transports of guests to events, transport of groups to exhibitions, fairs, conferences, social events, tours. 


\section{X.4. Results}

The average values of evaluation of individual statements for Importance and Performance were presented in Figure 2 and 3. Then these pairs of statements (Performance; Importance) were placed on the map and presented in Figure 4.

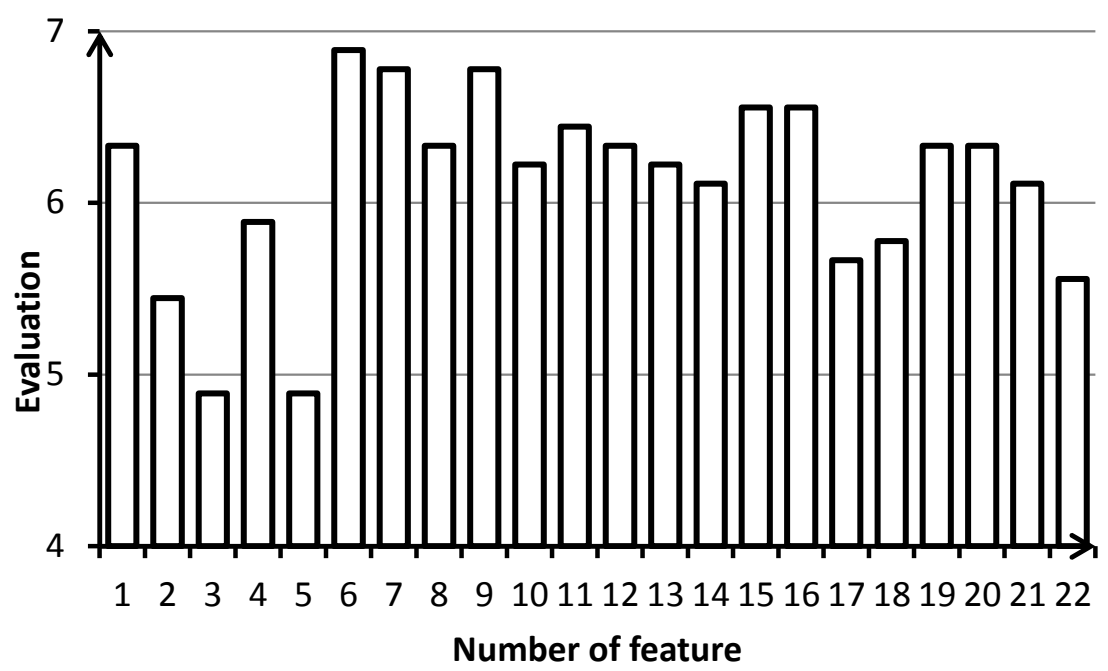

Fig. 2. Aggregated results for the importance of customers in relation to the model transport service company.

Source: based on INGALDI M., WYWIAL S. 2015

From Figure 2 it results that the greatest expectations for the transport services concerned: keeping the conditions of the contract (statement 6), having a flawless documentation relating to individual contracts (statement 7) and being sensitive to the needs of individual clients (statement 9). In contrast, the customers had the smallest expectation when it comes to: neat look of the staff (statement 3), convenient location of the company (statement 5). It should be noted that 15 put of 22 expectations were evaluated at an average of over 6 . 


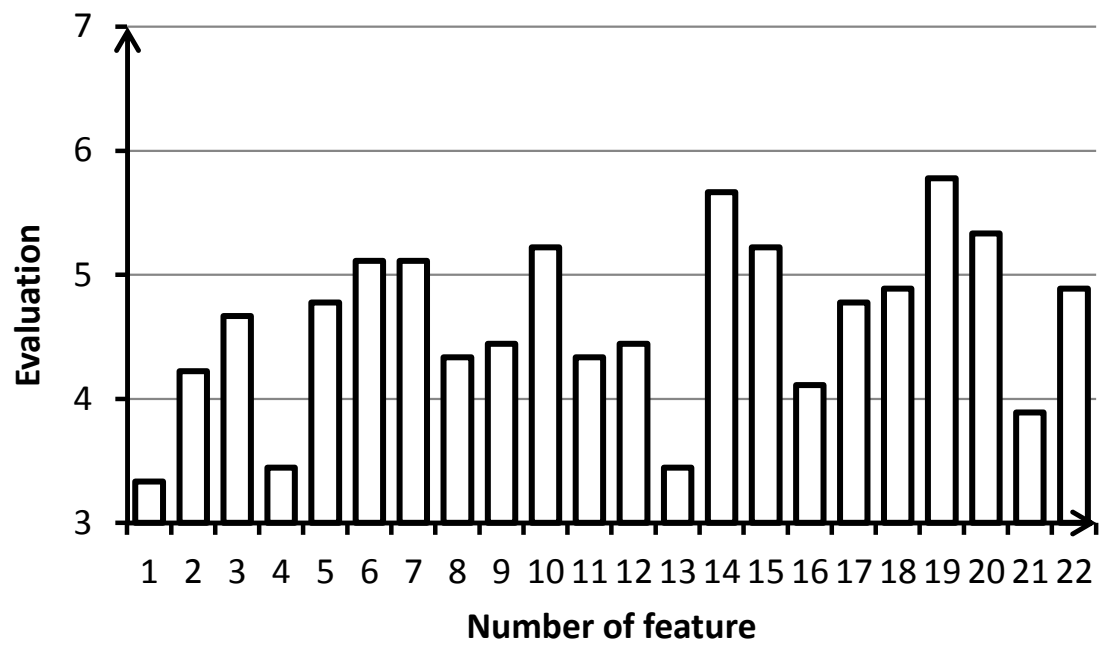

Fig. 3. Aggregated results for the performance of customers in relation to the research transport service company.

Source: based on INGALDI M., WYWIAL S. 2015

Analysing Figure 3 and comparing it to Figure 2 immediately it is possible to notice that none of the statements in the research transport company has been evaluated at level 6 or above. Generally Performance was lower than Importance. The highest evaluations of the research company were obtained in the case of: treating each customer individually (statement 19) and well qualified staff (statement 14). Customers evaluated the lowest: modern transport fleet (statement 1), promotional materials and Internet website (statement 4) and smoothly and quickly working staff (statement 13). 


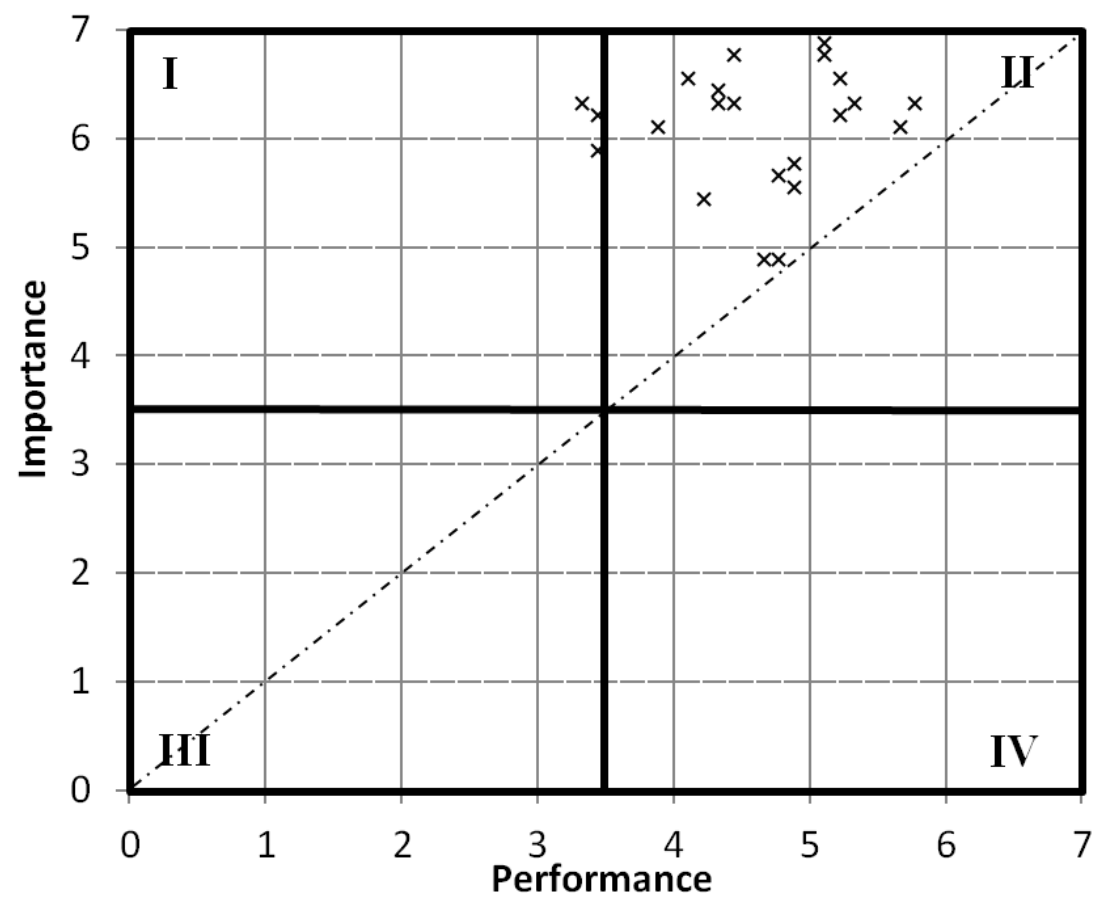

Fig. 4. Importance/Performance map for transport service.

Source: own study

As it was mentioned before, the closer to the diagonal of the map the point is located, the more its performance is correlated with the needs of customers. It should be noted that the pair of evaluations placed as points in Figure 4 lie above the diagonal. This means that in all cases the expectations were higher than the received service.

Two average evaluations were placed the closest to the diagonal, they were: convenient location of the company (statement 5) and neat look of the staff (statement 3 ). This means that despite of the low evaluations of these two features in case of the research company, these characteristics meet the expectations of customers. They are correlated to the needs (expectations) of the customers. 
Most of the points (pairs of evaluations) were placed in Quadrant II labelled as "Keep up the good work", notated as High Importance/High Performance. This means that the characteristics of transport services offered by the research company are in the area of reasonable property of needs.

The research company should not be worried too much about the level of its services despite the large differences between the expectations of customers' towards to transport service and its actual performance. Of course it can think about correction in the fields where the differences were high but it is not quickly required.

\section{Summary}

In the chapter the analysis of the transport services offered by the company from southern Poland was conducted. For this purpose the Importance/Performance analysis was used. The conducted research revealed that the quality of the transport service was placed in Quadrant II: High Importance/High Performance. This means that the improvement of the quality by raising the level of implementation of individual statements of the transport services is not necessary.

The research showed that the validity of the use of Importance/Performance analysis. The research with use of Servqual method presented in paper (INGALDI M., WYWIAL S. 2015) showed that many of the features of the transport service (statements contained in the questionnaire) need to be improved, as noted major difference between customer expectations and the perceptions of the transport service delivered by research company. However, the use of Importance/Performance analysis showed that indeed, efforts to improve the relationship between these expectation and perception can be improved. But from the point of view of the quality of research transport services, it is not quite as necessary as it may seem.

Perhaps it is worth to consider whether conducting research with use of the Servqual method, the same time not to use additionally 
Importance/Performance analysis. The data used in Servqual method can be analyzed with use of the Importance/Performance analysis. What is important, this analysis can show whether the changes are really necessary, and the method Servqual will show what changes should apply at first.

\section{Bibliography}

1. Dziuba S.T., SZOŁTYSEK K., Kozyra C. 2011. Application of FAM - Fail Assessment Method - to optimization of unit costs of producing flours for . special purposes. [In:] Improvement of Production Process. Ed. Borkowski S., Krynke M., Publisher TRIPSOFT, Trnava, pp.28-39.

2. INGALDI M. 2013. The implementation of the Servqual method in the courier services company. International Journal Transport \& Logistics, Issue 26, volume 13.

3. INGALDI M., JURSOVA S. 2013. Wykorzystanie metody Servqual do badania satysfakcji klientów punktu obstugi indywidualnego klienta dystrybucji gazu. Rynek Energii, No 4 (107), pp. 43-47.

4. Ingaldi M., WyWIAL S. 2015. Ocena jakości uslug przewozowych z wykorzystaniem metody Servqual. [In:] XXIII Międzynarodowa Konferencja Naukowo-Techniczna "Produkcja i Zarządzanie W Przemyśle" Zakopane, 1 - 3.07.2015 - article in press.

5. LESTYÁNSZKA ŠKŮRKOVÁ K., INGALDI M. 2014. Recycling process of the aluminium cans as an example of the renewable material sources. Advanced. Materials Research. Vol. 1001, pp 103-108.

6. Martilla J.A., JameS J.C. 1977. Importance - Performance Analysis. Journal of Marketing. January, pp. 77-79.

7. RADKOWSKI K. 2005. Metody i techniki badan jakości w sferze ustug. [In:] Rynkowe mechanizmy kształtowania jakości. Wyd. URz. Rzeszów.

8. Stoma M. 2012. Modele i metody pomiaru jakości ustug. Q\&R Polska Sp. z o.o., Lublin.

9. URBANIAK A. M. 2013. Zastosowanie metody SERVQUAL do oceny jakości uslug rekreacyjnych. Zeszyty Naukowe Uczelni Vistula. Poznań. 
10. Wong M.S., HideKI N., GEORGE P. 2011. The Use of ImportancePerformance Analysis (IPA) in Evaluating Japan's E-government Services. Journal of Theoretical and Applied Electronic Commerce Research. Vol. 6, Issue 2, August, pp. 17-30. 